\title{
Considerations regarding the evolution of COVID-19 in the South-Muntenia Region between June 11 and August 31, 2020
}

\author{
Rodica Manuela Gogonea ${ }^{1}$ \\ ${ }^{1}$ The Bucharest University of Economic Studies, Romania \\ E-mail: manuela.gogonea@csie.ase.ro
}

\begin{abstract}
Internationally, after the Second World War, the health and economic sector is facing a major challenge with a new disease: COVID-19. The transmission of the virus was quite fast so that the population of each country was affected. Given that quite a few cases of COVID-19 infection have been reported both internationally and regionally for Romania, we considered it important to observe and analyze the evolution of this disease in Taking into account the daily number of COVID-19 infections in each county in the South Muntenia region, between June 11 and August 31, 2020, the research included the analysis of evolutions of absolute and relative values compared to the total of Romania, the region included in the study, from one county to another or overnight. The results showed an overall growth trend for each county, mainly for Argeș, Prahova and Dâmbovița. Thus, it is necessary both to take new measures appropriate to the existing situation, customized at the level of each county, and to comply as drastically as possible with the measures to eliminate and prevent COVID-19 disease.
\end{abstract}

Keywords: COVID-19, counties, South Muntenia Region, Romania

\section{Introduction}

The year 2020 began with the rapid spread of the COVID-19 pandemic, which caused thousands of deaths worldwide. This has led to an international public health concern declared by the WHO since 30 January 2020 [1].

The problems facing the pandemic are many and quite little known. They have a spatial dimension that requires a detailed and in-depth approach [2]. In terms of health, there is a gradual need for research into the different dimensions and spatial aspects of disease and medicine. They intertwine spatial analysis, spatial-temporal dimensions with demographic aspects of health, presenting evidence of health inequalities and pandemics. [3, 4].

In this context, the concept of health geography can be highlighted with a predominantly utilitarian and analytical perspective in the territory. It includes structuralize approaches, either as a cultural and sociological view of social welfare, or as a sense of "place" for people [5].

Like any infectious disease, its rapid spread endangers public health by requiring important measures and actions, starting at the community level, then at the regional level and last but not least at the national level. In this context, due to measures that encourage hygiene and social distancing, the damage caused by blocking economic and social life has been gradually recognized in all countries. The measures taken were varied. 
They have undergone a different evolutionary trajectory from one state to another, including issues aimed at either intensifying hygiene by carefully washing hands, or closing certain units from small shops, restaurants, pubs, to malls, and even to banning public meetings. Governments have gradually resorted to quarantine of vulnerable people and restrictions on national and international travel [6].

In this context, Romania has gone through difficult situations, a fact confirmed by the number of cases that are quite high, from one period to another. Thus, during the pandemic, Romania faced different experiences and implemented various health and economic policies, at different times and in different forms, in order to end the pandemic and economic activities appropriate to the context were carried out, with favorable investments.

However, as in other countries [7,8], the heterogeneity of its impact in geographical areas was acute, people with high incomes abruptly reduced spending in mid-March 2020, enterprises laid off most low-income employees, leading to a rising unemployment in the more economically developed regions. At the same time, macroeconomic instruments in the form of stimulating aggregate demand or providing liquidity to enterprises had a reduced capacity to restore jobs because consumer spending was constrained by health problems.

At the Romanian level, considering the need to identify and develop for the future both health policies and economic and social strategies, the paper presents a dynamic, spatial explanatory description of the distribution of COVID-19 cases by counties, during 11 June - August 31, 2020, at the level of the South Muntenia region. The research elaborated from June 11 to August 31, 2020 focused on studying the evolution of COVID-19 during the summer. The aim is to conduct future research in the fall and maybe even winter, studying the differences that occur in the evolution of the disease from one season to another. The results obtained could be supplemented with aspects that highlight the impact in economic and social terms, thus determining, specifying and adopting measures to be applied in order to economic recovery of the South-Muntenia region.

Thus, the introductory part of the article is followed by a framework for presenting the characteristics of the number and weights of COVID-19 cases determined at the level of the period included in the analysis. In the chapter results and discussions are presented multiple aspects that highlight a general growth trend.

After presenting the evolution of the share of cases registered in the South Muntenia region between June 11 and August 31 in the total number of COVID-19 cases registered in Romania is analyzed both the number and the weights of COVID-19 cases registered until June 11 in counties of the South Muntenia region. The research continues with a rendering of the evolution of the total number of COVID-19 cases in the counties of the South Muntenia development region in the period included in the analysis.

The analysis of the evolutions of the daily increase of COVID-19 cases in the counties of the South Muntenia development region between June 11 and August 31 is followed by a description of the daily evolutions of the structural weights by counties for the number of COVID-19 cases in the South Muntenia development region. June 11 - August 31. The chapter ends with an overview of the number and weights of COVID-19 cases registered until August 31 in the counties of the South Muntenia region.

The article concludes with a chapter of conclusions that highlights that the counties of Arges, Prahova and Dâmbovița represent the counties of the South-Muntenia region which during the mentioned period registered the most significant increases in terms of the number of COVID-19 cases. In view of this fact, as a final conclusion it can be mentioned that, especially for these counties, it is necessary to adopt strict preventive measures and restrictions to be imposed and applied by local governments and health units involved in this extensive eradication process of COVID-19 disease. 


\section{Methodological aspects}

Taking into account the objective of the study to identify the evolution of COVID-19 disease in the counties of the South Muntenia region (Argeș, Călărași, Dâmbovița, Giurgiu, Ialomița, Prahova and Teleorman), seven variables were identified and used (Table 1).

Given the motivation to conduct the study, to identify and develop in the future health policies and strategies in economic and social terms during the article aimed to highlight the similarities and differences between them in terms of indicators analyzed, taking into account the data available in study period (June 11-August 31, 2020).

Table 1 List of variables

\begin{tabular}{|c|l|c|}
\hline No. & \multicolumn{1}{|c|}{ Variables } & Units \\
\hline 1 & The total number of COVID -19 cases in Romania (TNC_Rom) & number \\
\hline 2 & $\begin{array}{l}\text { Total number of COVID -19 cases in the South Muntenia development region } \\
\text { (TNC_SM) }\end{array}$ & number \\
\hline 3 & The total number of COVID -19 cases in county X (TNC_CX) & number \\
\hline 4 & Daily number of new COVID -19 cases registered in the county X & number \\
\hline 5 & $\begin{array}{l}\text { The share of the number of COVID -19 cases at the level of the South Muntenia } \\
\text { development region in the total number of cases registered in Romania }\end{array}$ & $\%$ \\
\hline 6 & $\begin{array}{l}\text { The share of the total number of COVID -19 cases in county X in the total number of } \\
\text { cases registered in the South Muntenia region }\end{array}$ & $\%$ \\
\hline 7 & $\begin{array}{l}\text { Share the daily number of new COVID -19 cases registered in county X in the total } \\
\text { number of cases registered in the South Muntenia region }\end{array}$ & $\%$ \\
\hline
\end{tabular}

The highlighting of the similarities and differences between the counties was based primarily on some important characteristics of the variables that represented basic indicators in the analyzes performed in the paper (table 2).

Table 2 Main characteristics of the total number of COVID -19 cases

\begin{tabular}{|l|l|r|r|r|r|r|}
\hline \multicolumn{2}{|c|}{} & \multicolumn{1}{|c|}{ Mean } & Median & Maximum & Minimum & Std. Dev. \\
\hline \multicolumn{2}{|l|}{ TNC_Rom } & 46122.63 & 39648 & 87540 & 21182 & 20948.00 \\
\hline TNC_SM & 7187.49 & 6131 & 15111 & 1668 & 4525.80 \\
\hline \multirow{7}{*}{} & TNC_CAG & 2464.54 & 2220.5 & 5017 & 306 & 1686.01 \\
\cline { 2 - 7 } & TNC_CCL & 276.05 & 245 & 540 & 109 & 121.85 \\
\cline { 2 - 7 } & TNC_CDB & 1485.15 & 1271 & 3080 & 342 & 931.96 \\
\cline { 2 - 7 } & TNC_CGR & 384.96 & 329 & 690 & 237 & 136.20 \\
\cline { 2 - 7 } & TNC_CIL & 641.18 & 606.5 & 962 & 397 & 198.37 \\
\cline { 2 - 7 } & TNC_CPH & 1635.22 & 1218 & 4230 & 130 & 1321.401 \\
\cline { 2 - 7 } & TNC_CTL & 300.39 & 241 & 592 & 147 & 147.85 \\
\hline
\end{tabular}

Between June 11 and August 31, 2020, out of the average number of COVID-19 cases determined in Romania (approximately 46123 cases), $15.58 \%$ is represented by the one registered for the South Muntenia region (approximately 7188 cases).

The analysis of the average number of COVID-19 cases at the level of each county, shows that Argeș County is on the first place with 2465 cases, i.e. $34.29 \%$ of the average of the South Muntenia region, registering the highest amplitude of diseases of 4711 cases compared to other counties. Less, with approximately 829 cases, Prahova County is also in the top of the ranking by the average number of diseases, given that it represents $22.75 \%$ of the average of the region. 
With a difference of only 150 cases compared to Prahova, Dâmbovița ranks third with a fairly large amplitude of 2741 cases. At a difference of approximately 844 cases compared to the first three counties and approximately 256 cases compared to the last three counties in the ranking, Ialomita County is in the middle of the ranking.

The lowest shares in the number of COVID-19 cases registered in the South Muntenia region, of $5.36 \%$, respectively $4.18 \%$ and $3.84 \%$ of the total are registered in Giurgiu, Teleorman and Călărași counties.

Starting from these basic indicators (the total number of COVID-19 cases in Romania, the one in the South Muntenia development region and the total number of COVID-19 cases in the component counties of that region), as well as their characteristics, the analysis of the evolutions of the cases of COVID-19 diseases was further approached both in number and in weight compared to the total of Romania, of the region included in the study, from one county to another, as well as from one day to another.

\section{Results and discussions}

The study begins with an analysis of the share of COVID-19 cases registered in the South Muntenia region in the total number of cases in Romania.

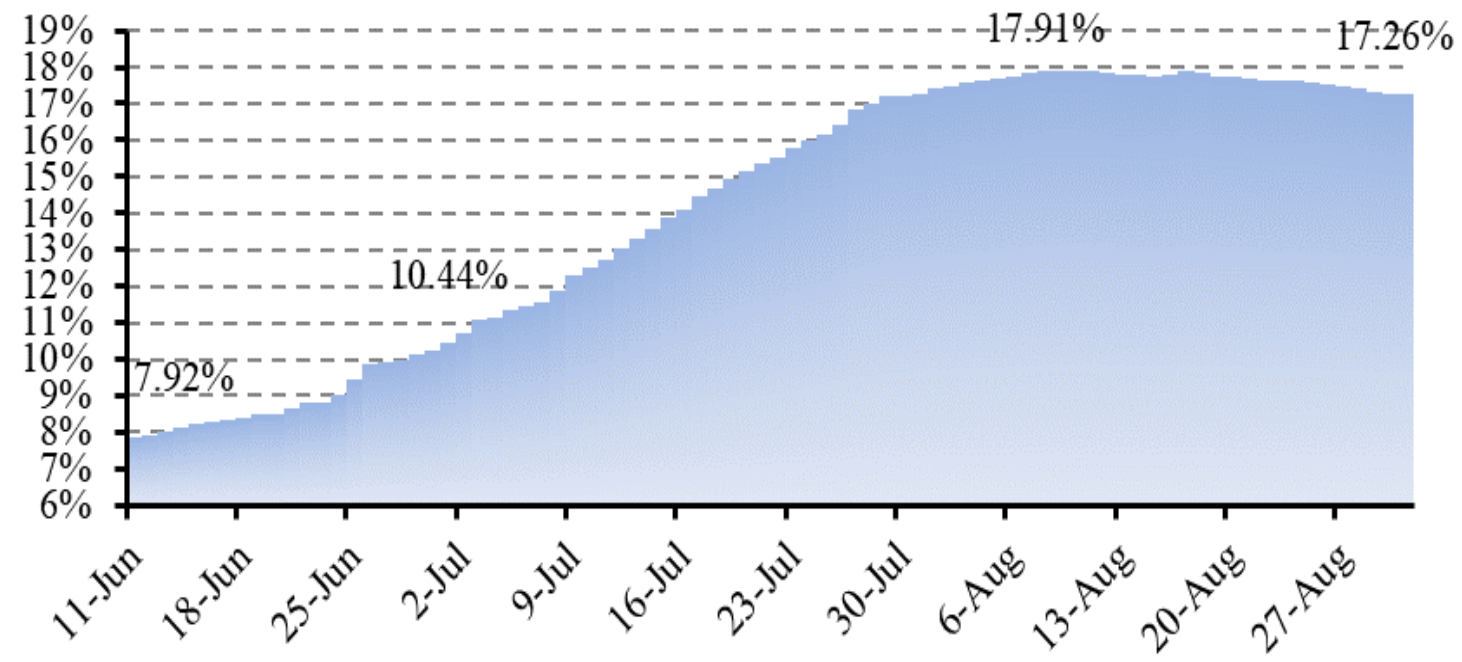

Figure 1 Evolution of the share of the number of cases registered in the South Muntenia region between June 11 and August 31 in the total number of COVID-19 cases registered in Romania

Figure 1 shows very clearly the sharp increase from one day to another, the weights of the number of cases in the South Muntenia region compared to the total number of COVID-19 cases in Romania, from $7.87 \%$ determined on June 11 to $17.91 \%$ when they were calculated for the 17th of August. During this period there are exceptions on June 19 and 20 when the share is the same of $8.52 \%$, respectively on June 22 and 23 when the same percentage of $8.82 \%$ is determined.

A small fluctuation occurs on July 29, 30 and 31 when percentages of $17.20 \%, 17.18 \%$ and $17.28 \%$ are recorded. In the next analysis period (August 17-August 31), the cases were lower, a fact noted by the decreasing weights from one day to another from 17.82\% from August 18 to $17.26 \%$ on August 31. 


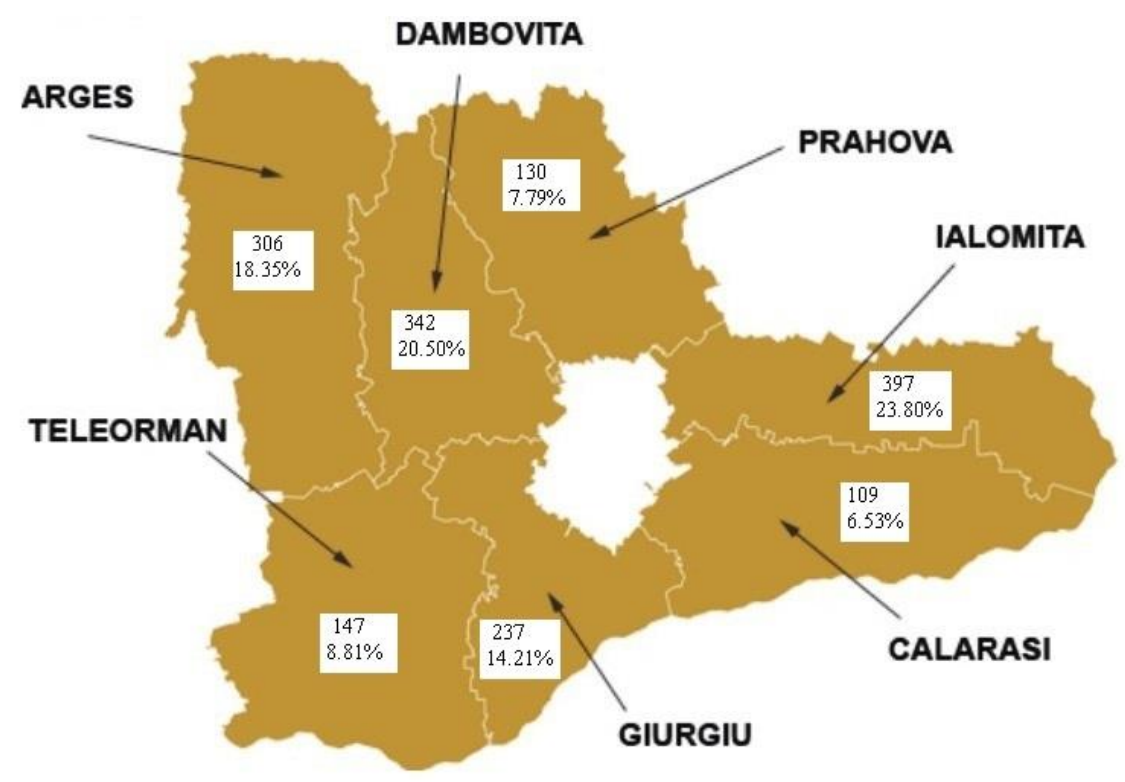

Figure 2 Number and weights of COVID-19 cases registered until June 11 in the counties of the South Muntenia region

With over 300 COVID-19 cases registered until June 11, Ialomița, Dâmbovița and Argeș counties are at the top of the ranking, representing $23.80 \%, 20.50 \%$ and $18.35 \%$ of all cases in the South Muntenia region. With 237 cases, Giurgiu County has $14.21 \%$ of the total in the South Muntenia region. The ranking of counties in relation to the number and weights of COVID-19 cases registered until June 11 in the counties of the South Muntenia region places the counties on the last places with over 100 cases: Teleorman (with $8.81 \%$ in the total region), Prahova (with $7.79 \%$ ) and Călărași with $6.53 \%$ (figure 2 ).

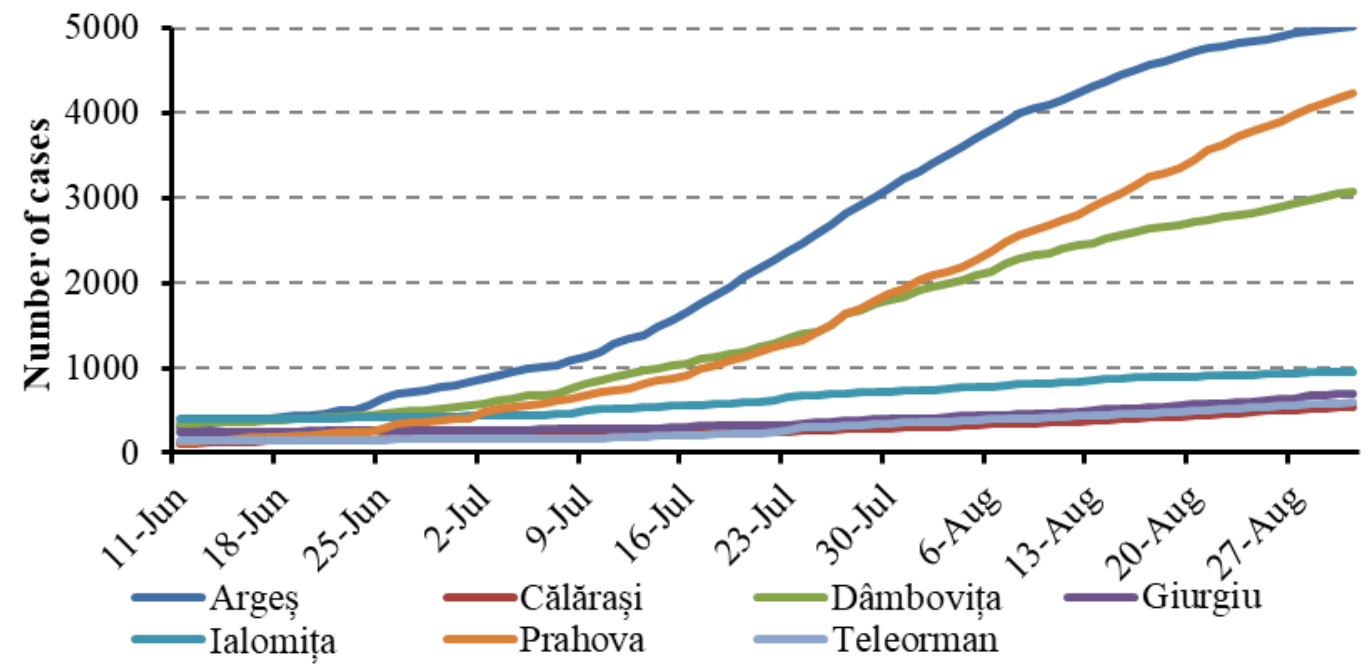

Figure 3. Evolutions of the total number of COVID-19 cases in the counties of the South Muntenia development region between June 11 and August 31

After June 11 to August 31, in the South Muntenia region, the evolution of the number of COVID19 cases is constantly increasing, but it differs numerically from one county to another (figure 3). Thus, Argeș County registers the highest increase, with approximately 58 cases / day (from 306 cases on June 11 to 4711 cases on August 31), followed by Prahova with approximately 51 cases / day (from 
a minimum of 130 cases to a maximum of 4100 cases) and of Dâmbovița with approximately 33 cases / day (minimum 342 cases, maximum 2708 cases). With a maximum of 565 cases on August 31 from 397 cases to June 11, the average increase was determined to approximately 7 cases / day for Ialomita County. Giurgiu, Teleorman and Călărași represent the counties with the lowest average increase in cases registered between June 11 and August 31, of approximately: 6 cases / day in the case of the first county, 5 cases / day for the last two.

Taking into account the number of COVID-19 cases from each day compared to the previous day, starting with June 11, at the level of each county was determined the daily increase whose evolution is shown in Figure 4. Thus, on June 23, the lowest increase in the number of COVID-19 cases is registered on the whole of the South Muntenia development region, with only 19 cases in addition to the previous day (June 22), which represents a growth rate daily by only $0.89 \%$. At this date, the distribution of the daily increase in cases by counties is different. Thus, Dâmbovița County registers the most significant increase ( 9 cases more than in the previous day), compared to the other counties (the rate is $2.10 \%$ ). This county is followed by Ialomița and Prahova (5 cases more than on June 22 ).

Although they have only 5 more cases than on June 22, the daily growth rates are different: Ialomita has an increase of $1.22 \%$, and Prahova County with $2.13 \%$ on June 23 compared to June 22 . Călărași County registers only 1 case more on June 23 than the previous one, represented by a rather low daily growth rate, by $0.68 \%$. On June 23 , the counties of Argeș, Giurgiu and Teleorman registered the same number of cases as on June 22 (of 510 cases - Argeș, 255 cases - Giurgiu, respectively 154 cases - Teleorman)

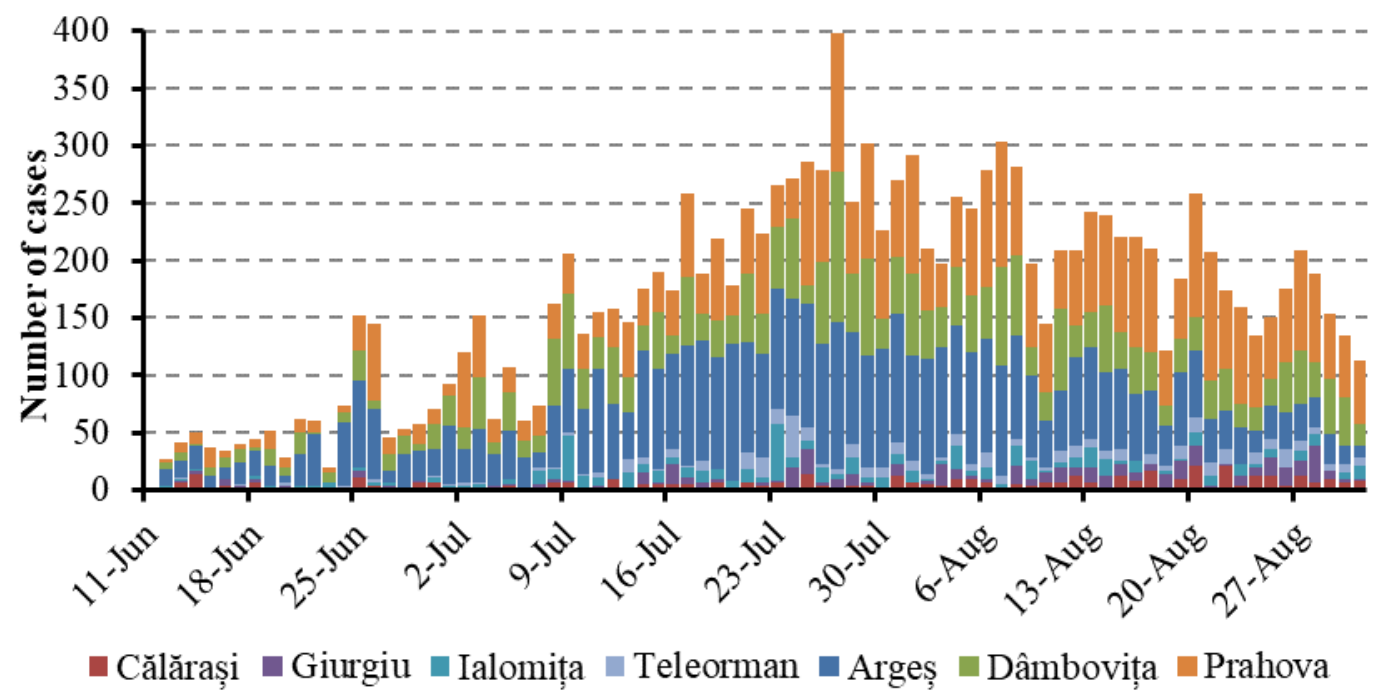

Figure 4. The evolutions of the daily increase of COVID-19 cases in the counties of the South Muntenia development region between June 11 and August 31

At the level of the South Muntenia development region, the biggest increase in the number of COVID-19 cases is on July 27, when there are 398 more cases than on July 26, the zinc rhyme of growth being $5.42 \%$. The distribution of the daily increase in cases by counties on the mentioned date varies. Thus, the most significant increases in July 27 compared to the previous day are reported in Dâmbovita counties with a cynical increase of 131 cases and a rate of $8.73 \%$, Argeș with 129 cases, respectively 4.80\% and Prahova with 120 cases representing 7.94\%. Then, for Giurgiu County, the difference between the two days of analysis is 9 cases, which represents a relative increase of $2.43 \%$. The situation of the increase from one day to another on July 27 compared to July 26 is the same for Ialomița and Teleorman with 4 cases, but with different rates of $0.58 \%$ for the first county and $1.28 \%$ for the second. Regarding Călărași County, the difference of July 27 compared to the previous day is also 1 case, as on June 23 , only that the daily growth rate is only $0.36 \%$. 
Between June 11 and August 31, as mentioned, the counties of Dâmbovița, Argeș and Prahova correspond to the most significant increases on July 27. Ialomita has a maximum increase of 50 daily cases COVID-19 on July 23 compared to July 22 transposed in a relatively daily increase of $8.21 \%$, followed by Teleorman with a daily increase of 36 cases on July 24 (by 13.74\%) and Giurgiu with 32 cases on August 28 for which the daily growth rate is $4.95 \%$. Călărași County registers the highest daily increase in cases on August 20, with 21 cases transposed by a relatively daily increase of $4.99 \%$.

The total number of COVID-19 cases from the counties of the South Muntenia development region between June 11 and August 31 allowed the determination of the structural weights that in time, from one county to another, had significant fluctuations (figure 5).

At the level of the South Muntenia development region, the structural weights for the number of COVID-19 cases of Argeș and Prahova counties compared to those of the other counties, changed from one day to the next in the sense of an increasing trend over the entire analysis period at $18.35 \%$ and $7.79 \%$ (June 11) at $37.08 \%$ and $27.99 \%$ (August 5 and August 31).

The general trend of reduction of the structural weights determined by region at the county level is manifested first of all in Ialomița, the oscillation being of 16.74 percentage points between the maximum of $23.80 \%$ on June 11 and the minimum of $6.34 \%$ from August 30 and Giurgiu with 10.06 percentage points maximum of $14.21 \%$ on June 11 and minimum of $4.15 \%$ on August 7). The same decreasing trend, however, is recorded by only 5.16 percentage points for Teleorman County (maximum of $8.81 \%$ on June 11 and minimum of $3.65 \%$ on August 16) and only by 4.22 percentage points for Calarasi (from $7.36 \%$ on June 18 to $3.14 \%$ on August 9). Dâmbovița represents the county with the smallest oscillation of the number of COVID-19 cases compared to other counties, the structural weights being only between the minimum of $18.85 \%$ from June 26 and the maximum of $22.04 \%$ from July 12 .

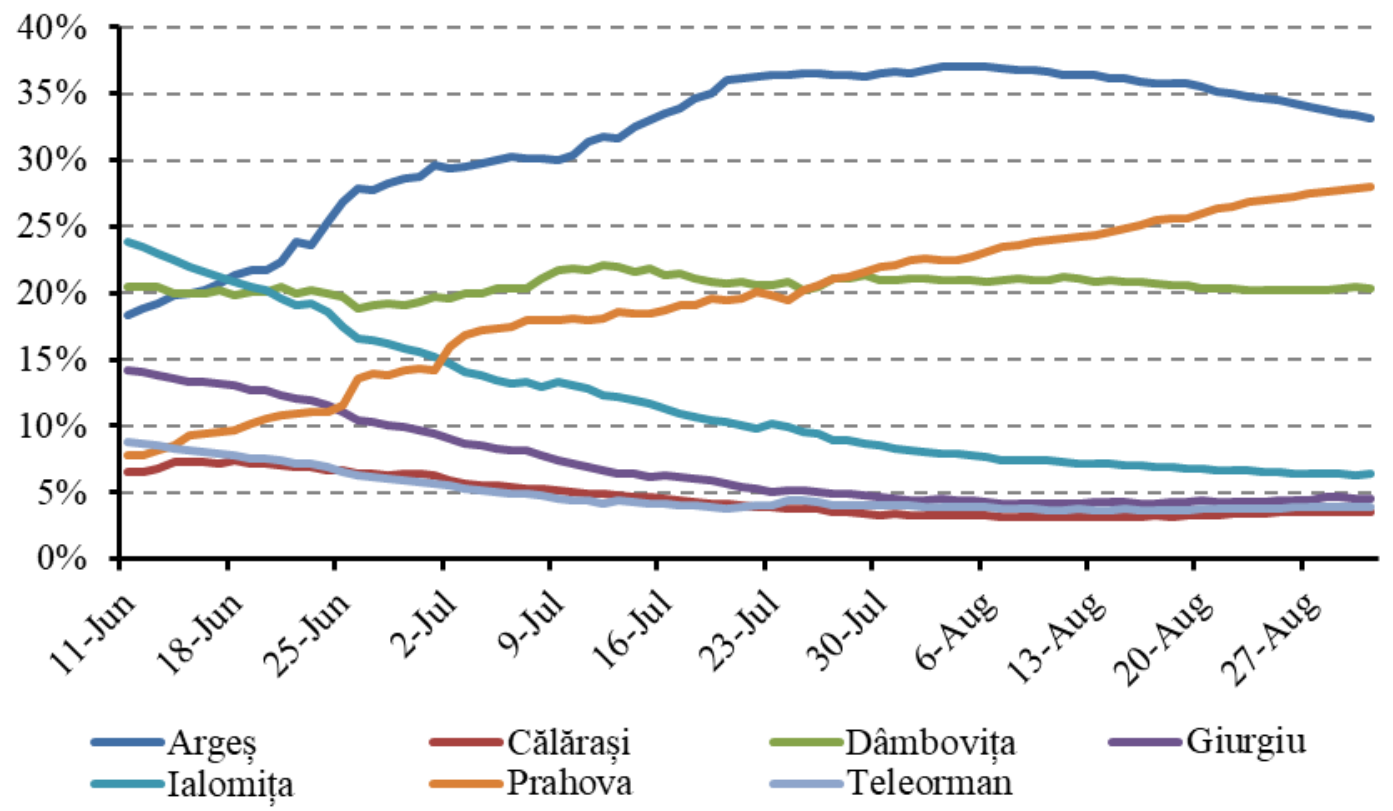

Figure 5. Daily evolutions of the structural weights by counties for the number of COVID-19 cases at the level of the South Muntenia development region between June 11 and August 31 


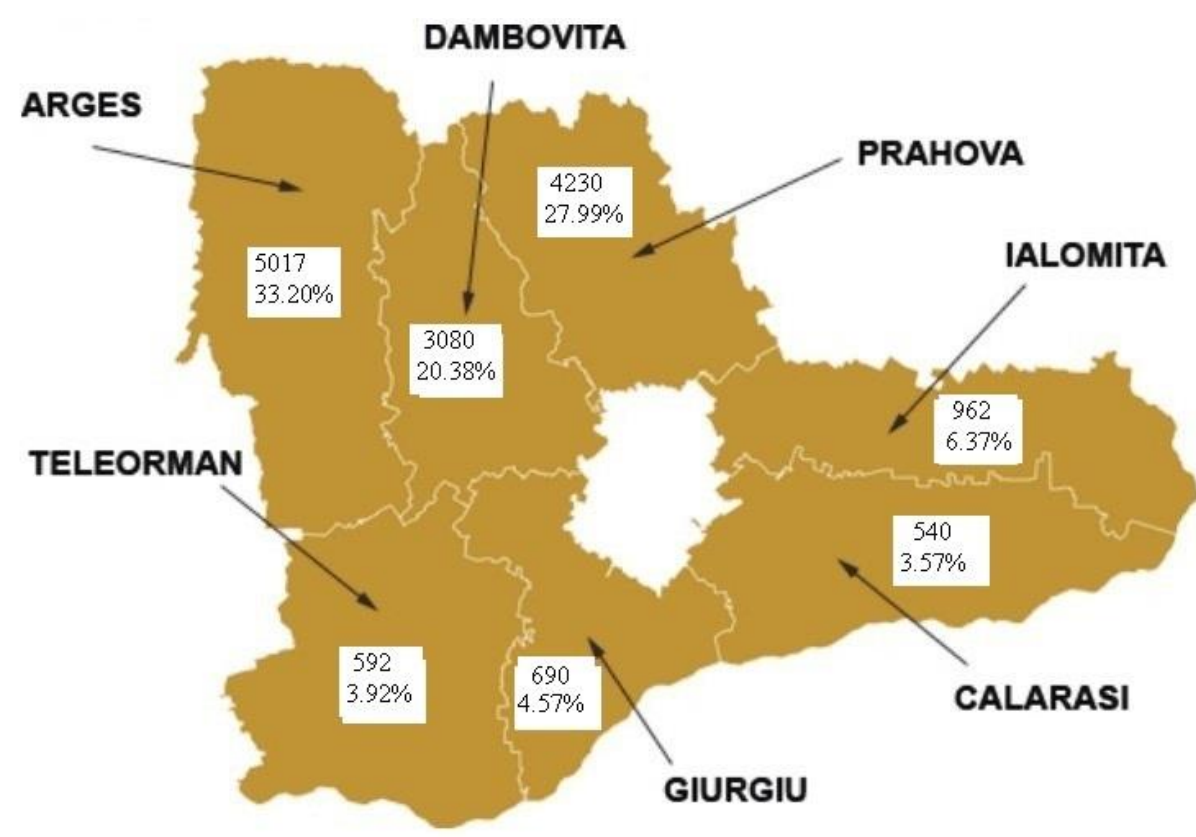

Figure 6 Number and weights of COVID-19 cases registered on August 31 in the counties of the South Muntenia region

If the analysis carried out during the article started with a presentation of the number and weights of COVID -19 cases registered on June 11 in the counties of the South Muntenia region, it will end with the presentation of the level of the same indicators but on August 31 (figure 6). Thus, it can be mentioned that Argeș County has faced a significant increase in COVID -19 cases. The process of rapid spread (growth) of the disease brought it to the first place on the last day of analysis (August 31) compared to the first day (June 11) in which it ranked third.

With 4711 more cases than in June 11 in the South Muntenia region, compared to other counties, this county has $33.20 \%$. Prahova is the second county with serious problems in terms of the spread of the disease. It rose in the ranking of COVID-19 cases, returning to August 31, 27.99\%, given that at this time their number is 4100 cases higher than the first day of analysis when it was on the penultimate place. Dâmbovița remains among the first three counties with a large number of cases (2738 more cases than on June 11) which, compared to the other counties, has a percentage of $20.38 \%$.

Ialomita, from the first place occupied on June 11, reaches the fourth place on August 31, with 962 COVID -19 cases, representing 6.37\% of the total cases of the South Muntenia region. At the same time, on August 31, Giurgiu County has a higher number of cases than on June 11, but, compared to the other counties, a small number, the percentage being only $4.57 \%$.

The last two places are occupied by Teleorman with 3.92\% of the total cases of the South Muntenia region (445 cases more than those registered on June 11) and Călăraşi with $3.57 \%$ (compared to the number of cases registered on June 11 are more with 431 cases).

The last two places are occupied by Teleorman with $3.92 \%$ of the total cases of the South Muntenia region (445 cases more than those registered on June 11) and Călărași with $3.57 \%$ (compared to the number of cases registered on June 11 are more with 431 cases)

\section{Conclusions}

Knowledge of COVID-19 dynamics at the regional level is important to clarify the magnitude and impact of the pandemic. This context creates the necessary premises for the adoption and implementation of decisions at the level of local and implicitly regional communities. In this sense, the study offers an analysis of the evolutions of COVID-19 cases at the level of each county in the SouthMuntenia Region, under different aspects, for the entire period from June 11 to August 31. 
The evolution of the number of COVID-19 cases registered in the South Muntenia region in the total number of cases registered in Romania is highlighted in the form of the weights determined for the period June 11 - August 31. If from June 11 to August 17 there were increasing weights from one day to another, in the next period, until August 31, they will be oscillating below the maximum value of $17.91 \%$.

The most drastic situation, due to the large number of COVID-19 cases and the corresponding weights by counties compared to the total registered in the South Muntenia region is encountered until June 11 in Ialomița, Dâmbovița and Argeș, and on August 31 in Argeș, Prahova and Dâmbovița. If Giurgiu is placed in the middle of the ranking on June 11, until the end of the analysis period, the place of this county is taken by Ialomița. Furthermore, if by June 11 the counties of Teleorman, Prahova and Calarasi, in descending order, face fewer cases of infection than those recorded in the South Muntenia region, the situation is quite good on August 31 for Giurgiu, Teleorman and Calarasi.

The evolutions of the total number of COVID-19 cases, between June 11 and August 31, are different from one county to another. The largest increases in the number of COVID-19 cases from one day to the next were reported for the counties of Argeș, Prahova and Dâmbovița. In the middle of the ranking is Ialomița, followed by Giurgiu, Teleorman and Călăraşi counties with the smallest daily increases in the number of COVID-19 cases.

At the level of the South Muntenia development region, the smallest increase and daily rhythm (minimum values) is registered on June 23, when, compared to June 22, the smallest increase in the number of COVID-19 cases is observed from one day to the next. . At the mentioned date, taking into account the two reference indicators (daily increase and rhythm), the counties of Dâmbovița, Ialomița and Prahova correspond to the most significant increases. The three counties are followed in ranking by Călărași County, and the lowest daily increments and rhythms on the mentioned date belong to Argeș, Giurgiu and Teleorman counties. Regarding the fastest increases (maximum values of increase and daily rate) recorded in the same region included in the analysis, the date of July 27 can be reported. And by counties, in July 27 compared to July 26, the most significant increases are registered for the counties of Dâmbovița, Argeș, and Prahova. These counties are followed by Giurgiu County, so that the last three counties, Ialomița, Teleorman and Călărași correspond to the lowest daily increments and rhythms.

The analysis of the evolution of the increase and of the daily rhythm of COVID-19 cases on each of the counties of the South Muntenia development region, between June 11 and August 31 places, through the highest values, on the first place Dâmbovița, Argeș and Prahova on July 27 , followed by Ialomița on July 23. With lower values are Teleorman County on July 24, followed by Giurgiu on August 28 and Calarasi County with the highest daily increase in cases on August 20.

Comparing daily the number of cases in each county with the one in the South-Muntenia region, the determined weights allowed the presentation of some evolutions between June 11 and August 31 . The evolutions show that the structural weights for Argeș and Prahova changed from one day to the next in the sense of an increasing trend over the entire analysis period, compared to those of the other counties. For the rest of the counties, the structural weights registered a rather significant decrease. The exception is Dâmbovița County, which, during the entire study period, the number of COVID-19 cases compared to the one in the region as a percentage, compared to the other counties, oscillates insignificantly from one day to the next, highlighting a fairly constant evolution.

The regional distribution of COVID-19 cases can be explained by environmental conditions, various social processes, including those based on unplanned population growth, social inequalities, living standards and civilization [9]. This statement considers on the one hand the deficient water infrastructure, and on the other hand the built infrastructure, in the South Muntenia region, i.e. the availability of water and the relations between the prevalence and the level of overcrowding. At the same time, socio-economic factors in the region are targeted with significant spatially significant impact on the spread of COVID-19 cases, such as social processes that shape the epidemiological vulnerability of localities, overcrowding and access to health services, which require the design of urban and health policies effective. 
Understanding the distribution of the number of cases confirmed by COVID-19 in the counties of the South Muntenia Region is relevant for the elaboration of health policies, future economic and social strategies, aspects that should be included in the 2030 Sustainable Development Goals.

A critical analysis of current literatures shows that considerable changes will occur in local, regional and international trade patterns. Thus, the trajectory from boom, recession, changing environment to general trade policies will return to the forefront for many countries [10].

The paper provides useful information and provides a perspective for future bibliographic queries as a resource for understanding the evolution of tools used in the management of this pandemic. At the same time, it represents an opening of future research that should include other development regions in Romania.

The decisions to be taken against COVID-19 should be tailored to the spatial-temporal dimensions and demographic aspects of health. In this way they must represent challenges from an interdisciplinary perspective, imposing proactive planning, and international solidarity in close interdependence with the global perspective.

\section{References}

[1] Hamzaha F A B, Laub C H, Nazric H, Ligotd D V, Leee G, Tanf C L, Shaibg M K B M, Zaidonh U H B, Abdullahi A B, Chungj M H, Ongk C H, Chewl P Y, Salungam R E, 2020, Corona Tracker: worldwide COVID-19 outbreak data analisys and prediction, Bull World Health Organ, doi: http://dx.doi.org/10.2471/BLT.20.255695; /10079/20

[2] BM Napoletano, F Rosete-Verges, L Billa, 2020 Spatial analysis and GIS in the study of COVID19. A review, Science of the Total Environment, 739, 140033, www.elsevier.com/locate/scitotenv, https://doi.org/10.1016/j.scitotenv.2020.140033

[3] C Bambra, R Riordan, J Ford, F Matthews, 2020 The COVID-19 pandemic and health inequalities, J Epidemiol Community Health, 10.1136/jech-2020-214401, http://jech.bmj.com/

[4] Dorn Avan, Cooney RE, Sabin ML, 2020 COVID-19 exacerbating inequalities in the US. Lancet; 395:1243-4

[5] Kearns, R., Moon, G., 2020 From medical to health geography: novelty, place and theory after a decade of change, Progres. Hum. Geogr. 26 (5), 605-625.

[6] R Rowthorn, J Maciejowski, 2020 - A cost-benefit analysis of the COVID-19 disease, Oxford Review of Economic Policy, Volume 36, Number S1, pp. S38-S55, https://academic.oup.com/oxrep/article/36/Supplement_1/S38/5899017

[7] R Chetty, JN Friedman, N Hendren, M Stepner, 2020 How did covid-19 and stabilization policies affect spending and employment? a new real-time economic tracker based on private sector data, NBER Working Paper, No. 27431, DOI: 10.3386/w27431, https://www.nber.org/papers/w27431 https://iepecdg.com.br/wp-content/uploads/2020/06/tracker_paper.pdf,

[8] G Bonaccorsi, F Pierri, M Cinelli, 2020 Economic and social consequences of human mobility restrictions under COVID-19, PNAS July 7, 117 (27) 15530-15535; https://doi.org/10.1073/pnas.2007658117

[9] D Sinha, P Manna, 2020 The effect of Lockdown due to Covid-19 on Post-traumatic Stress and Depression among College Students of Kolkata, hotspot district of West Bengal, India, IOSR Journal Of Humanities And Social Science (IOSR-JHSS), Volume 25, Issue 5, Series 9 (May. 2020) 58-64 e-ISSN: 2279-0837, p-ISSN: 2279-0845, www.iosrjournals.org, DOI: $10.9790 / 0837-2505095864$

[10] KM Shuaib, 2020 The Changing Pattern of International Trade: Import Substitution Policy and Digital Economy in Nigeria. A Review, IIARD International Journal of Economics and Business Management, Vol 6. No. 4, E-ISSN 2489-0065 P-ISSN 2695-1878, www.iiardpub.org; http://iiardpub.org/get/IJEBM/VOL.\%206\%20NO.\%204\%202020/The\%20Changing\%20Patter n\%20of\%20International.pdf 